Економічні науки: збірник наукових прачь Луиького національного технічного університету. - Серія “Регіональна економіка". - Випуск 15 (59). - Редкол.: відп. ред. д.е.н., професор Л.Л. Ковальська. - Луиьк: ІВВ Луиького НТУ, 2018. - 292 с.

УДК 332.12

Фесіна Ю.Г., Дзюбинська О.В.

Луцький національний технічний університет

\title{
ЦИРКУЛЯРНА ЕКОНОМІКА - ЯК НОВА ПАРАДИГМА РЕГІОНАЛЬНОГО РОЗВИТКУ
}

Забезпечення раціонального виробництва та споживання вимагає пошуку нової економічної моделі. Розглянуто сутність моделі циркулярної економіки. Визначено основні принципи іiі функціонування. Запропоновано вирішувати проблему відходів на регіональному рівні через імплементацію моделі циклічної економіки. Наведено пропозиції для забезпечення функціонування моделі циклічної економіки в регіоні з метою реалізації цілі раціонального виробництва й споживання.

Ключові слова: сталий розвиток, циркулярна економіка, відходи, рециклінг, регіональний розвиток

\section{Yu. Fesina, O. Dzyubynska}

\section{CIRCULAR ECONOMY - AS A NEW PARADIGM OF REGIONAL DEVELOPMENT}

Sustainable consumption and production patterns need looking new economic model. The new model appeared recently and is called the circular economy. A circular economy provides for creating new business models, accelerating economic growth, and improving lives in regions.

In a circular economy, the value of products and materials is maintained for as long as possible. Waste and resource use are minimised, and when a product reaches the end of its life, it is used again to create further value. This can bring major economic benefits, contributing to innovation, growth and job creation. A circular economy encourages sustainability and competitiveness in the long term. A circular economy can help to: preserve resources - including some which are increasingly scarce, or subject to price fluctuation; save costs for produsers; unlock new business opportunities; build a new generation of innovative, resource-efficient regional businesses - making and exporting clean products and services around; 
Економічні науки: збірник наукових прачь Луиького національного технічного університету. - Серія “Регіональна економіка". - Випуск 15 (59). - Редкол.: відп. ред. д.е.н., професор Л.Л. Ковальська. - Луцьк: ІВВ Луиького НТУ, 2018. - 292 с.

create local low and high $\square$ skilled jobs; create opportunities for social integration and cohesion.

A circular economy helps to solve the problem of waste. Accumulation of waste is a problem to be solved at the regional level. Accumulation of waste and the necessity of expanding landfill sites and their placement will activate local communities in solving the problem of introducing a separate method for the collection of solid domestic wastes. A circular economy has the potential to positively affect everyone's lives and everything we buy for a more sustainable future. One company or one industry doing this alone will not be enough. A network of companies, territorial communities, working and innovating together, is what will help lead this transformation into the future.

Key words: sustainable development, circular economy, waste, recycling, regional development.

Фесина Ю.Г., Дзюбинская О.В.

\section{ЦИРКУЛЯРНАЯ ЭКОНОМИКА - КАК НОВАЯ ПАРАДИГМА РЕГИОНАЛЬНОГО РАЗВИТИЯ}

Обеспечение рационального производства и потребления требует поиска новой экономической модели. Рассмотрены сущность модели циркулярной экономики. Определены основные принципы ее функционирования. Предложено решать проблему отходов на региональном уровне через имплементацию модели циклической экономики. Приведены предложения для обеспечения функционирования модели циклической экономики в регионе с целью реализации цели рационального производства и потребления.

Ключевые слова: устойчивое развитие, циркулярная экономика, отходы, рециклинг, региональное развитие

Постановка проблеми у загальному вигляді та їі зв'язок із важливими науковими та практичними завданнями. Перехід більшості національних економік на модель сталого розвитку не лише закцентував увагу на глобальних проблемах світового розвитку, але й обумовив необхідність обгрунтування моделей протидії небезпечним викликам сьогодення. Останні мають на меті консолідувати зусилля світового співтовариства для досягнення спільних цілей та вирішення завдань, зокрема в сфері ліквідації бідності, подолання нерівності та створення гідних умов життя, усунення негативних проявів кліматичних змін. Вирішувати ці завдання передбачається через виконання 17 цілей сталого розвитку, 
Економічні науки: збірник наукових прачь Луиького національного технічного університету. - Серія "Регіональна економіка". - Випуск 15 (59). - Редкол.: відп. ред. д.е.н., професор Л.Л. Ковальська. - Луиьк: ІВВ Луиького НТУ, 2018. - 292 с.

які є частиною Порядку денного сталого розвитку на період до 2030 р., прийнятого світовими лідерами на саміті ООН у 2015 р.

Однією 3 ключових цілей $\epsilon$ забезпечення переходу до раціональних моделей виробництва та споживання, адже цей цільовий вектор поєднує в собі як економіку, так і соціальну сферу й екологію. Використання раціональних моделей виробництва й споживання передбачає раціональне освоєння й ефективне використання природних ресурсів, а також зменшення втрат продовольства у виробничо-збутовому ланцюзі, скорочення харчових відходів, раціональне використання хімічних речовин, зменшення обсягів відходів шляхом вживання заходів щодо запобігання їх утворенню, скорочення, переробки та повторного використання.

Аналіз останніх досліджень, у яких започатковано вирішення проблеми. Модель традиційної економіки не здатна в повній мірі вирішити поставлені завдання, а тому виникає необхідність у застосуванні нової економічної моделі. Такої моделі, яка акцентує увагу на пошуку раціональних шляхів збереження ресурсів і водночас забезпечує динаміку економічного росту. Вона з'явилася відносно недавно й носить назву моделі циркулярної (кругової) економіки. Цільова спрямованість моделі полягає в зменшенні обсягів утворення відходів і збільшення обсягів їх переробки та повторного використання на основі інноваційних технологій та виробництв.

Питання ресурсозбереження розглядаються в працях I. Сотник [1], Л. Мельника, С. Скокова [2], Л. Мусіної, Т. Кваші [3]; дослідження стану поводження 3 твердими побутовими відходами висвітлені в працях М. Щурика, О. Надраги [4], Є. Крикавського, А. Костюк та О. Шандрівської [5].

Пропозиції з імплементації засад циркулярної економіки в механізм формування та реалізації державної політики отримали теоретичне обгрунтування та практичні рекомендації в працях В. Свдокимова та Л. Сергієнко [6-7]. Сутнісний зміст циркулярної моделі економіки розглядає I. Зварич, котра до традиційних 3R принципів іiі функціонування додає четвертий. Так, поряд зі скороченням (Reduce), повторним використанням 
Економічні науки: збірник наукових прачь Луиького національного технічного університету. - Серія “Регіональна економіка". - Випуск 15 (59). - Редкол.: відп. ред. д.е.н., професор Л.Л. Ковальська. - Луиьк: ІВВ Луиького НТУ, 2018. - 292 с.

(Reuse) та переробкою (Recycle) дослідниця пропонує розглядати принцип глобальної соціальної корпоративної відповідальності (Responsibility) [8].

Цілі статті. Обгрунтування необхідності реалізації положень циркулярної економіки в систему поводження з відходами на регіональному рівні.

Виклад основного матеріалу дослідження 3 повним обгрунтуванням отриманих наукових результатів. У більшості регіонів країни економіка функціонує за лінійною моделлю. За цієї моделі відбувається інтенсивне використання природних ресурсів, відходи від використання яких в основному накопичуються на земельних ділянках, забруднюючи їх. Окрім централізованих місць накопичення відходів, 3'являється проблема виникнення несанкціонованих звалищ відходів на земельних ділянках, які не мають статусу полігонів відходів. У лінійній моделі можуть сповідуватися принципи вторинного використання відходів (наприклад, переробка металобрухту, макулатури, пластику), що дозволяє говорити про певну сполучну ланку між лінійною та циркулярною моделями. Однак модель циклічної економіки вимагає значно більшої консолідації зусиль. Насамперед, йдеться про зміну системи цінностей, психології як зі сторони споживачів, так і зі сторони виробників благ.

Впровадження пропонованої моделі вимагає від виробників інноваційних підходів до зміни технологій виробництва, підвищення рівня відповідальності за виготовлений продукт на всіх етапах його життєвого циклу. Циркулярна економіка дозволяє продовжити життєвий цикл продукту, шляхом трансформації його цінності та підтримки ланцюга створення вартості настільки, наскільки це можливо. Відтак, у бізнесу з'являються нові можливості для залучення альтернативних ресурсів, продукти (відходи) одного виробництва стають сировиною для іншого, зменшуються ризики від дефіциту та нестабільності цін традиційних ресурсів. Розвиток отримує не лише великий, але й малий та середній бізнес, які долучаються до програм вторинної переробки та 
Економічні науки: збірник наукових прачь Луиького національного технічного університету. - Серія "Регіональна економіка". - Випуск 15 (59). - Редкол.: відп. ред. д.е.н., професор Л.Л. Ковальська. - Луцьк: ІВВ Луичького НТУ, 2018. - 292 с.

створення нових продуктів, що сприяє приросту робочих місць. Паралельно з виробничим сектором дістає можливості для розвитку логістика, сфери дизайну та маркетингу. Модель циркулярної економіки трансформує лінійного виробника продукції в смарт-виробника, який ще на стадії створення продукту знає й розуміє, як в кінці його життєвого циклу можна буде далі надати «нового» життя продукту, трансформувавши його, та скільки реально буде отримано відходів, які потрібно утилізувати.

Таким чином, модель циркулярної економіки дозволяє оптимізувати сферу поводження 3 відходами та більш краще планувати потужності створення, використання полігонів для розміщення відходів. Переваги моделі для навколишнього середовища полягають у збереженні біорізноманіття, зменшення забруднення повітря, земель та води.

Світовий досвід свідчить, що циркулярна модель економіки вже включена до інструментів політики управління відходами. Так, спільнота країн СС виробила спільну мету до 2030 р. досягти переробки побутових відходів на рівні $65 \%$, переробки відходів упаковки - на рівні $75 \%$, захоронити на полігонах побутових відходів максимум 10 \% відходів. Також передбачається заборонити захоронення на полігонах відходів, які збираються роздільно; просувати економічні інструменти для зменшення захоронення відходів; спростити, вдосконалити та гармонізувати методи визначення ставок утилізації відходів на всьому просторі ЄС [9].

У контексті реалізації заходів щодо досягнення цілі відповідального споживання та виробництва, в Україні передбачається зменшити обсяг утворення відходів і збільшити обсяг їх переробки та повторного використання на основі інноваційних технологій та виробництв. Зокрема, передбачається зменшити обсяг утворених відходів від усіх видів економічної діяльності 3 977,4 кг у розрахунку на 1000 дол. США ВВП (за ПКС 2011 р.) до 800 кг/1000 дол. США в 2030 р. Питому вагу спалених та утилізованих відходів у загальному обсязі утворених відходів пропонується довести 3 
Економічні науки: збірник наукових прачь Луиького національного технічного університету. - Серія “Регіональна економіка". - Випуск 15 (59). - Редкол.: відп. ред. д.е.н., професор Л.Л. Ковальська. - Луцьк: ІВВ Луиького НТУ, 2018. - 292 с.

$30 \%$ в 2015 р. до $55 \%$ в 2030 р. [10]. Як бачимо, національна стратегія не акцентує уваги на питанні деталізації інструментів забезпечення скорочення відходів, хоча автори доповіді зазначають, що досягнення поставленої цілі передбачає в тому числі й запровадження моделі циркулярної економіки. Головним чином вона зводиться до фокусування уваги на енергозбереженні, регенеративному екологічно чистому виробництві та споживанні; оптимізації виробничо-збутових ланцюгів продовольства 3 метою мінімізації втрат на всіх етапах життєвого циклу [10, с. 95].

Вважаємо, що великою перепоною для реалізації в Україні моделі циркулярної економіки є відсутність мотивації суб'єктів бізнесового середовища в частині формування бізнес-процесів, сфокусованих на скороченні відходів та їх повторному залученні у продуктовий ланцюг. Зважаючи на рівень інноваційної активності бізнесу, можна стверджувати, що шанси переходу країни на модель циркулярної економіки низькі.

Так, існуючий науково-технічний потенціал країни, як спадок минулих десятиліть, не здатен нині забезпечити інноваційний прорив й орієнтований він на модель лінійної економіки. Забезпечити ефективність хоча б лінійної економіки він уже неспроможний. Внаслідок цього частка країни у світовому обсязі торгівлі високотехнологічною наукомісткою продукцією становить 0,1 \%. У загальному обсязі реалізованої продукції переробної промисловості в 2013 р. питома вага видів діяльності 3 високим рівнем технологій становила лише $3,9 \%$ [11, с. 103].

Більшість відходів в Україні підлягає захороненню. На утилізацію спрямовується близько $34 \%$ загальної кількості утворених відходів, спалюється близько $0,25 \%$ відходів і близько $62 \%$ розміщується у спеціально відведених місцях та об'єктах. У середньому на одну особу в країні за рік припадає 220-250 кг відходів, а в міських агломераціях - 330-350 кг [11, с. $115-116]$.

Проблема утворення відходів має територіальну прив'язку, а тому їі вирішення вимагає регіонального підходу. 
Економічні науки: збірник наукових прачь Луиького національного технічного університету. - Серія “Регіональна економіка". - Випуск 15 (59). - Редкол.: відп. ред. д.е.н., професор Л.Л. Ковальська. - Луцьк: ІВВ Луиького НТУ, 2018. - 292 с.

Накопичення відходів та необхідність розширення полігонів їх розміщення активізують місцеві громади в питанні вирішення задачі запровадження роздільного способу збирання твердих побутових відходів, упорядкування полігонів побутових відходів. Наприклад, жителі однієї 3 територіальних громад поблизу м. Луцьк самостійно свідомо зорганізувалися для забезпечення збору сміття за допомогою спеціалізованого автомобіля та маркованих мішків. Наступним етапом планується облаштування майданчиків для сортування сміття.

Зазначимо, що в регіональному розрізі набагато доступніше реалізовувати програми формування екологічної свідомості населення, працюючи з цільовими віковими групами населення. Адже брак системної роботи в цьому сегменті не дозволяє підходити до вирішення проблеми на однаковому ментальному рівні. Як наслідок - виникають несанкціоновані звалища відходів та гальмується можливість впровадження програм із роздільного збору відходів. Так, наприклад, у м. Луцьк було виділено два пілотних спальних мікрорайони для відпрацювання зазначеної технології. Муніципалітет встановив спеціальні контейнери для збирання відходів за різними категоріями (суха та мокра фракції, ПЕТ-пляшка). Однак більшменш вдало вдалося відсортовувати лише ПЕТ-пляшки. Інші відходи змішувалися. Хоча, слід зазначити, окремі підприємства, що функціонують у місті, сповідують принципи бережливого виробництва й тим самим, через корпоративну культуру, формують екосвітогляд працівників. Наприклад, на луцькому підприємстві «Модерн-Експо» - найбільшому виробникові торгівельного обладнання в країні, існує короткостроковий курс введення у філософію бережливого виробництва. На підприємстві використовують систему $5 \mathrm{~S}-$ сортування, акуратність, підтримка порядку, чистота, формування звички. Це приклад того, як бізнес може долучатися до виховання екологічної свідомості населення через систему корпоративного навчання.

У Волинській області, відповідно до реалізації цілі відповідального споживання та виробництва, планується 
Економічні науки: збірник наукових прачь Луиького національного технічного університету. - Серія “Регіональна економіка". - Випуск 15 (59). - Редкол.: відп. ред. д.е.н., професор Л.Л. Ковальська. - Луцьк: ІВВ Луичького НТУ, 2018. - 292 с.

скоротити обсяги утворених відходів I-IV класів небезпеки 3 638,8 тис. т в 2015 р. до 400 тис. т у 2030 р., тобто на $37 \%$ протягом 30 років. Також, протягом планового періоду, планується зменшити чисельність діючих сміттєзвалищ на 44 одиниці - 3514 у 2015 р. до 470 в 2030 р. [12]. Загальна площа всіх сміттєзвалищ в області становила в 2015 р. 390 га. Також в експлуатації перебуває 11 полігонів твердих побутових відходів, які розміщені в обласному центрі, містах обласного підпорядкування та в районних адміністративних центрах. При цьому три полігони (Ковель, Шацьк, Любомль) вже вичерпали свій ресурс для приймання сміття. Близькою до критичної $\epsilon$ ситуація з полігонами в м. Луцьк та м. Нововолинськ.

Зазначимо, що досягти планового показника скорочення чисельності сміттєзвалищ можна лише за умови інтенсифікації заходів із запровадження роздільного збирання сміття. Наприклад, цілком реально відсортовувати пластик, картон, папір, скло, одяг, а також ПЕТ-тару. Відсортовані відходи підлягають здачі на підприємства, які заготовляють вторинну сировину. При цьому в Україні вже існують потужності для переробки пластику, скла, паперу, гумових виробів. Однак проблемною $є$ переробка специфічних видів відходів батарейок, люмінесцентних ламп, комбінованої упаковки.

Відходи у вигляді органічних решток можуть вивозитися на полігон, де цілком реально добувати 3 них альтернативну енергію. Водночас для сприяння зменшенню утворення відходів, на етапі виробництва мають обиратися сприятливі до довкілля матеріали, продумуватися те, куди упаковка чи продукція потрапляе після використання споживачем. Вирішення проблеми відходів на основі реалізації моделі циркулярної економіки можливе на умовах існування розширеної відповідальності виробника. Товаровиробники мають відповідати за переробку та утилізацію своєї продукції після іiі споживання. Тому виробники разом із місцевими громадами зобов'язані приймати активну участь в організуванні роздільного збору відходів, облаштуванні сортувальних ліній та сприяти переробці відходів. Таким чином, застосування 
Економічні науки: збірник наукових прачь Луиького національного технічного університету. - Серія "Регіональна економіка". - Випуск 15 (59). - Редкол.: відп. ред. д.е.н., професор Л.Л. Ковальська. - Луцьк: ІВВ Луиького НТУ, 2018. - 292 с.

сучасних технологій переробки відходів без залучення бізнесу, інновацій неможливе. Останнє вимагає пошуку нових технологій переробки. Наприклад, технологія термічної переробки сміття $є$ екологічно чистою й такою, що наближає рівень переробки сміття до $100 \%$. Одним із важливих напрямів локалізації відходів $€$ інвестування в будівництво сміттєпереробних потужностей закритого типу. Такі проекти $є$ дороговартісними, тому їх фінансування може здійснюватися за рахунок об'єднання інвестиційних ресурсів територіальних громад, підприємницьких структур.

Висновки. Реалізація основних положень циркулярної економіки на регіональному рівні дозволить сформувати нову систему економічних відносин у сфері розробки, виробництва, розподілу, споживання, збирання та рециклінгу продукції. Впровадження бізнес-моделі циркулярної економіки в систему регіональних господарських відносин сприятиме зменшенню навантаження на ресурси, мінімізує негативні зовнішні впливи на природне середовище. Це також дозволить значно краще координувати регіональні заходи в сфері управління відходами, консолідувати зусилля та можливості територіальних громад у реалізації кращих практик збору та переробки відходів.

Для того, щоб модель циркулярної економіки отримала свої прикладне застосування в сфері раціонального виробництва та споживання потрібні регіональні цільові програми, які б пропонували механізм більш тісної взаємодії територіальних громад iз представниками бізнесового сектору, розвитку державно-приватного партнерства, містили набір інструментів мотивації виробників та споживачів. Упровадження моделей пайового фінансування, часткова компенсація кредитних зобов'язань, що виникають при інвестуванні в переробні потужності дозволять залучити фінансові потоки в сферу поводження та переробки відходів. У бюджетах об'єднаних територіальних громад слід обов'язково щорічно виділяти статтю витрат на заходи 3 організування роздільного збору сміття та підтримки його утилізації. Додатково слід здійснити корективи податкового законодавства - в частині скасування 
Економічні науки: збірник наукових пращь Луцького національного технічного університету. - Серія “Регіональна економіка". - Випуск 15 (59). - Редкол.: відп. ред. д.е.н., професор Л.Л. Ковальська. - Луиьк: ІВВ Луиького НТУ, 2018. - 292 с.

податку на додану вартість для тих товарів, які вироблені 3 вторинної сировини. Таким чином, перспективи подальших досліджень прикладного застосування моделі циркулярної економіки в регіональному розвитку системи раціонального виробництва та споживання вимагають чіткого опису та деталізації економічного інструментарію їі підтримки.

1. Сотник I.M. Економічні основи ресурсозбереження: навч. посіб. Суми: Університетська книга, 2013. 284 с.

2. Мельник Л., Скоков С., Сотник И. Эколого-экономические основы ресурсосбережения: монография. Сумы: Университетская книга, 2006. 229 с.

3. Мусіна Л.А., Кваша Т.К. Ресурсоефективна економіка: європейські тенденції та уроки для України. Економічний аналіз: зб. наук. праць. 2014. Том 18. № 1. С. 51-62.

4. Щурик М.В., Надрага О.Р. Організаційно-економічні засади збирання, складування та утилізації твердих побутових відходів та сміття: макрорегіональний розріз. Статистика Украӥни. 2017. № 1. С. 40-46.

5. Крикавський Є.В., Костюк А.С., Шандрівська О.Є. Відповідальне поводження 3 твердими побутовими відходами: парадигми та контраверсії. Вісн. нац. ун-ту «Львів. політехніка». 2017. № 863. С. 101-109.

6. Свдокимов В.В., Сергієнко Л.В. Механізм формування та реалізація державної політики циркулярної економіки. Вісник Київського національного університету імені Тараса Шевченка. Держсавне управління. 2017. № 1. C. $22-31$.

7. Сергієнко Л.В. Впровадження циркулярної економіки в Україні: державно-управлінський аспект: канд. наук 3 держ. управл.: 25.00 .02 / Житомир. держ. технолог. ун-т. Житомир, 2017. 262 с.

8. Зварич I. Циркулярна економіка i глобалізоване управління відходами. Журнал європейської економіки. 2017. № 1. С. 41-57.

9. Review of Waste Policy and Legislation: веб сайт Європейської комісії. URL: http://ec.europa.eu/environment/waste/target_review.htm (дата звернення: 12.12.2018).

10. Цілі сталого розвитку: Україна. Національна доповідь. Київ, 2017. $174 \mathrm{c}$.

11. Інноваційна Україна 2020: національна доповідь. Київ, 2015. 336 с.

12. Цілі сталого розвитку: Волинь. Регіональна доповідь. Луцьк, 2018. $82 \mathrm{c}$. 